\title{
Perfil espacial das microrregiões criativas no Brasil
}

\author{
Nathan Freire Borges (UFJF); \\ Rosa Livia Montenegro (UFJF)
}

\begin{abstract}
resumo:
As cidades criativas têm a capacidade de influenciar suas economias, unir agentes econômicos e beneficiar regiões vizinhas, garantindo uma interação demográfica e um estímulo para os atores locais preocupados com valores culturais e inovação. O objetivo geral do trabalho foi identificar, caracterizar e analisar o perfil espacial e a capacidade criativa das microrregiões brasileiras. Por intermédio da análise de componentes principais (ACP) e da análise exploratória de dados espaciais (AEDE) foram identificadas quatro categorias que caracterizam as microrregiões brasileiras, com base nos indicadores abordados literatura da área. Os resultados mostraram que as categorias das microrregiões criativas e desenvolvidas, das microrregiões densas e violentas, das microrregiões com potencial turístico e das microrregiões com dinamismo cultural e tecnológico exibem grandes diferenças em seu perfil criativo, aprofundadas pelas desigualdades econômicas e sociais do País.
\end{abstract}

palavras-chave:

Microrregiões criativas; Inovação; Economia Regional; Análise Multivariada.

Área Temática: 4.2 - Economias Regionais e Urbanas

Código Jel: C38, O10, R10. 


\section{1- Introdução}

A partir da nova dinâmica econômica e das novas formas de produção, as formas alternativas de economia ganharam força. É o caso da economia criativa, em que os estudos sobre o tema surgiram em países desenvolvidos, principalmente na Austrália e no Reino Unido, por volta de 1990 (MACHADO, 2016; OLIVEIRA, 2016). Mudanças sociais ocorridas na época, fizeram com que o foco, antes restrito às atividades industriais, se voltasse para atividades intensivas em conhecimento e capital intelectual, com o peso do setor de serviços (BENDASOLLI et al., 2009; MACHADO, 2016; OLIVEIRA, 2016).

Outro fenômeno do final do século XX importante consistiu na atuação da sociedade, isto é, em uma lógica pós materialista com base intelectual, o capital humano ganhou maior relevância, bem como sua capacidade de trabalho e troca de conhecimento (BENDASOLLI et al., 2009). Com isso, as transformações ocorridas nas cidades criativas tornam-se relevantes, uma vez que a partir delas, a sociedade passou a valorizar a qualidade de vida nas cidades e outras necessidades que vão além do básico (BENDASOLLI et al., 2009). As necessidades de ordem intelectual começaram a influenciar o processo de tomada de decisão dos agentes econômicos, como as empresas e os consumidores (BENDASOLLI et al., 2009). Ressalta-se ainda que a economia criativa constitui um caminho para a solução dos problemas da virada cultural do final do século XX, sendo uma alternativa para a saída da pobreza nas esferas social, regional e nacional (COSTA e SOUZA-SANTOS, 2011; LANDRY, 2008; MACHADO, 2016). Em outras palavras, sendo um campo de atividade rentável, ligada intrinsecamente ao desenvolvimento regional, pesquisas sobre a economia criativa revelam que o setor é capaz de impactar diversas cadeias produtivas (MACHADO et al, 2016; VIEIRA, SANTOS e CARNIELLO, 2012).

Uma vez que os resultados da economia criativa advêm da terceira revolução industrial e envolvem atividades de capital intelectual, destaca-se muitas oportunidades para os indivíduos, as cidades e os países gerarem riqueza e impulsionar o crescimento econômico (CORAZZA, 2013; COSTA e SOUZA-SANTOS, 2011). O destaque dado ao longo do trabalho será relacionado ao recorte microrregional, associando a economia criativa e a classe criativa como fatores centrais para que a região se torne um espaço criativo, utilizando os novos recursos supracitados para crescer e atrair empresas e pessoas (LANDRY, 2008).

Em países como os Estados Unidos, por exemplo, cerca de 11\% do PIB advinha do setor criativo, no ano de 2008. Além disso, a nível mundial, 7\% do PIB de 2008 foi gerado por setores criativos (UNCTAD/DITC, 2008), e em 2015, o mercado global de bens criativos gerou 509 bilhões de dólares na economia mundial (UNCTAD/DITC/TED, 2018).

A importância oferecida ao processo criativo nas regiões torna-se atrativo quando as mudanças sociais citadas desencadeiam o que Landry (2008) chama de uma crise urbana. A crise urbana origina-se com o desaparecimento das indústrias tradicionais uma vez que as mudanças sociais, como argumenta Bendasolli (2009), levam a perda da importância da manufatura, mas, em contrapartida, a aplicação de novos conhecimentos a produtos e serviços ganha força e conquista novos espaços (LANDRY, 2008). A crise se propaga uma vez que há um efeito extensivo sobre a falta de relevância da indústria tradicional. Nesse caso, novos modelos ganham força, isto é, o que antes moldava a cidade (proximidade com matéria-prima, transporte) perde relevância.

Assim como, os escritórios e as fábricas se tornam cada vez mais escassos, devido às mudanças da sociedade e dos meios de produção no contexto pós materialista (CORAZZA, 2013). Os setores criativos e a classe criativa representam um caminho para a superação de diversos problemas observados nas últimas décadas. Sendo assim o presente trabalho busca responder duas perguntas centrais: como podem ser caracterizadas as microrregiões brasileiras por meio dos indicadores de criatividade? Como essas microrregiões são distribuidas e quais os seus perfis no espaço criativo?

Ao analisar o modelo de economia alternativa, que rompe com as teorias neoclássicas de produção de consumo e de trabalho, com produtos e serviços que contam com modelos de produção baseados em capital humano e intelectual, o setor criativo chama a atenção pela capacidade de revitalização urbana, e de geração de emprego e renda (COSTA e SOUZA-SANTOS, 2011; MACHADO et al, 2016). No âmbito brasileiro, as exportações de serviços criativos, no ano de 2014, alcançaram US $\$ 1,808$ milhão, destacandose o setor de Pesquisa e Desenvolvimento (P\&D). Ressalta-se também o cluster de Recife (Porto Digital) que se apresenta como o centro de maior sucesso em termos de inovação digital abrigando 265 empresas e instituições (UNCTAD/DITC/TED, 2018). Em 2017, o "PIB criativo" representou 2,61\% da renda gerada no país e contou com 837,2 mil trabalhadores empregados formalmente no Brasil, para o mesmo ano (FIRJAN, 2019). Observa-se, também, que o setor criativo brasileiro apresenta potencial de crescimento superior à média mundial (PWC, 2017).

Desta forma, os objetivos do trabalho são: identificar as microrregiões criativas brasileiras com base em indicadores identificados de acordo com a literatura da área; caracterizar e observar o perfil espacial bem 
como a capacidade criativa das microrregiões. Para uma caracterização mais detalhada, será possível identificar o perfil das microrregiões criativas brasileiras, de acordo com variáveis relacionadas ao objeto de estudo. Dessa forma, será utilizado a Análise de Componentes Principais (ACP) na construção de indicadores com perfis de criatividade. Em seguida, a Análise Exploratória de Dados Espaciais (AEDE) mapeará os aglomerados microrregionais, com base nos perfis identificados pela ACP. É oportuno ressaltar que o recorte microrregional permitirá a observação das características mais significativas entre as regiões, atenuando a questão da heterogeneidade presente no recorte municipal.

Em suma, o presente trabalho busca contribuir para a literatura empírica no Brasil, tanto avançando em questões contemporâneas quanto nos estudos sobre o desenvolvimento das microrregiões criativas brasileiras, evidenciando a capacidade da classe criativa de gerar desenvolvimento e inovação para as regiões brasileiras.

O artigo foi estruturado da seguinte forma, no segundo item será apresentado a revisão de literatura, tendo como destaque o conceito de cidade criativa, a revisão empírica sobre as cidades criativas e o seu panorama atual e caracterizações. No terceiro item será destacado a metodologia a ser aplicada, a saber, a análise de componentes principais (ACP) e a análise exploratória de dados espaciais (AEDE), além da base de dados com a descrição das variáveis. Por fim, serão tecidas nos itens 4 e 5 os resultados e as conclusões do trabalho.

\section{2-Cidades criativas: uma análise conceitual}

\section{1- Referencial teórico}

O presente referencial teórico tem como objetivo explicar o conceito de cidade criativa, de acordo com as principais referências da literatura. Inicialmente, é relevante conceituar a economia criativa e seus setores, chamados setores criativos. As principais referências quando se determina a economia criativa e as cidades criativas são os autores Richard Caves, Richard Florida e Charles Landry. Os trabalhos fornecem bases teóricas importantes para os estudos desenvolvidos no Brasil.

Florida (2004) ressalta o debate sobre os centros criativos, pois segundo o autor, seriam aqueles que concentram a "classe criativa" e são ricos em tolerância, talento e tecnologia. Outras características retratam a cidade criativa como uma representação da cidade do futuro (STRICKLAND, 2011). É importante ressaltar a capacidade que as cidades criativas têm de afetar suas economias, unir grupos e se beneficiar de sua importância histórica, garantindo uma interação demográfica e um estímulo para os agentes preocupados com valores culturais e inovação. As cidades se tornam criativas por meio de diversas ações, de acordo com Kageyama (2011). Tais ações podem ser obras de artes públicas, bares, bandas locais ou edifícios. Kageyama (2011) ainda argumenta que a cidade criativa possui um constante sentimento de possibilidade sendo " $o$ sentimento de que algo está acontecendo, de que algo poderia acontecer e, de que esse algo será interessante." (p.55). Outros indicadores apresentados pelo autor podem ser representados por: espaços públicos, parques, ambientes convidativos que, de acordo com o autor, estimulam a criatividade da população e caracterizam a cidade como um espaço funcional e convidativo (KAGEYAMA, 2011).

Landry (2008) em seu livro destaca a importância da cidade criativa na nova economia do século XXI. O autor reflete sobre da necessidade de condições propícias ao fomento do pensamento criativo, uma vez que este possibilita enfrentar diversos problemas urbanos hoje presentes, desde desabrigados até o ambiente visual da cidade. À medida que existe incentivo para a criatividade, as soluções para os problemas pontuais se propagam, atingindo proporções ainda maiores. De acordo com Landry (2008) as cidades criativas contam com uma flexibilização vantajosa para lidarem com as mudanças do mundo cada vez mais dinâmico.

A infraestrutura das cidades criativas descritas por Landry (2008), que ele denomina como infraestrutura "soft" (suave), diz respeito às conexões estabelecidas entre os habitantes e os espaços públicos. Em outras palavras, as conexões refletem o espaço em que as pessoas se encontram e conversam em um ambiente que não é o local de trabalho nem suas casas. A existência desse tipo de espaço (cafés, bares, parques) é fundamental, uma vez que representam um território neutro e estimulante, configurando-se como um espaço confortável. Ao contrário, espaços com infraestruturas mal-conservadas e deterioradas (prédios, lojas, moradias) afetam negativamente os habitantes e o ambiente local, enquanto que lugares esteticamente agradáveis afetam positivamente a saúde mental e física da população (LANDRY, 2008).

Landry (2008) também argumenta que a criatividade é a "moeda" mais importante para as novas cidades, os indivíduos e as instituições, pois fomentam a criatividade e geram um fluxo de inovações que se transformam em ativos da cidade. Destarte, a criatividade é ainda mais sofisticada do que o capital puramente financeiro, uma vez que quebra a característica unidimensional deste, gerando uma base ainda maior para 
geração de riqueza (LANDRY, 2008). Dessa forma, lugares com alta concentração de talentos, ou também chamados como clusters de criatividade e pesquisa, possuem maior capacidade de solucionar problemas e gerar oportunidades.

É importante ressaltar que a economia do século XXI se caracteriza pela inovação e pela adaptabilidade. Sendo assim, as cidades criativas precisam de planejadores com uma visão além do tradicional, isto é, uma visão cujo talento, a habilidade e a criatividade sejam ativos tradicionais, como localização e recursos naturais. Cabe destacar que a tipologia de ativos criativos pode ser tangível (infraestrutura) ou intangível e simbólico (cultura, educação). Por fim, Landry (2008) enfatiza a importância do agrupamento para os setores criativos, pois a própria formação dos clusters atrai e amplia o talento, a habilidade e a infraestrutura criativa. No entanto, nem todo habitante de uma cidade criativa é necessariamente criativo, porém, as cidades criativas dependem de pessoas criativas com "mente aberta" e com coragem para inovar (LANDRY, 2008). O discurso de Landry (2008) assemelha-se ao pensamento de Florida (2004) que será abordado em seguida.

Florida (2004) é amplamente reconhecido na literatura de cidades criativas. Em seu trabalho, é realizado uma análise sobre as cidades dos Estados Unidos com base em dados censitários do país e entrevistas. Florida (2004) apresenta três teorias de crescimento regional: a teoria do capital social - onde o crescimento depende de laços fortes de comunidade; a teoria do capital humano - em que as pessoas são o principal impulso para o desenvolvimento e crescimento regional; E, por último, a teoria do capital criativo, em que o autor argumenta que a "classe criativa" é responsável pela geração de desenvolvimento econômico, produzindo bens e serviços inovadores e de alta tecnologia. A classe criativa atrai as empresas de alta tecnologia para onde esses estão e, diferentemente dos trabalhadores tradicionais, a classe criativa não se desloca por estímulos tradicionais, os integrantes da classe criativa vão para uma cidade buscando experiências, aceitação e diversidade (FLORIDA, 2004).

\section{2- Referencial empírico}

A partir do levantamento teórico realizado, o conceito de cidade criativa que será utilizado no trabalho representa a concentração da classe criativa (Florida, 2004) em uma cidade. De acordo com Florida (2004), uma cidade criativa concentra talento (educação), tolerância e tecnologia. O conceito é coerente com o de Landry (2008) e de Reis e Urani (2011) que serão apresentados a seguir, na revisão de literatura de trabalhos empíricos.

O trabalho de Florida (2004) examinou 49 regiões com mais de um milhão de habitantes. O autor utilizou as informações disponíveis para determinar os 3Ts - Tolerância, Talento e Tecnologia - de sua teoria do capital criativo. Os dados mostraram que 38,8 milhões de pessoas pertencem à classe criativa nos Estados Unidos, representando cerca de $30 \%$ da força de trabalho do país. Florida (2004) também constatou que a classe criativa que se afasta de cidades ricas em capital social, também se afastam de comunidades e empresas tradicionais em busca dos centros criativos. Tais centros criativos atraem os agentes da classe criativa, isto é, agentes que geram bens e serviços inovadores além do aumento da empregabilidade local. Por fim, a pesquisa de Florida (2004) indicou que os centros criativos possuem altos níveis de inovação e empresas de tecnologia, como por exemplo: São Francisco, Seattle, Chicago, Denver, Mineapolis.

Bille e Schulze (2006) fazem uma análise sobre o papel da cultura no desenvolvimento urbano e regional. Os autores relatam que há uma interdependência entre desenvolvimento urbano e desenvolvimento artístico-cultural, indicando que a dupla causalidade ocorre quando o desenvolvimento no setor cultural afeta, positivamente, o desenvolvimento urbano ao mesmo tempo em que o desenvolvimento econômico influencia, positivamente, o setor cultural. A dupla causalidade ocorre quando há desenvolvimento e as pessoas têm mais acesso a recursos, se tornando mais escolarizadas. A medida em que a demanda por bens culturais é positivamente dependente do nível educacional e do nível de renda, o próprio desenvolvimento das cidades provocará maior demanda por bens culturais, o que fomentará o setor criativo.

Os autores descrevem a importância da cultura como caminho para a regeneração e desenvolvimento urbano regional com efeitos de curto e longo prazo. Os efeitos de curto prazo seriam baseados no turismo cultural, na presença de arte e cultura na região. Esse movimento atrai visitantes de outras regiões e os efeitos podem ser diretos (emprego e renda gerados pelas atrações artísticas); induzidos (gastos dos visitantes); indiretos (efeitos multiplicadores dos outros dois). O efeito de longo prazo é o ambiente artístico e cultural que se desenvolve e se transforma em um fator de atração para pessoas e empresas em busca de experiências providas por tais setores culturais (BILLE, SCHULZE, 2006).

Martins (2011) fez uma análise sobre Lisboa, capital de Portugal, como cidade criativa. O autor introduz o seu trabalho ressaltando a ideia de cidade criativa proposta por Florida (2004) e destaca o fator do 
turismo cultural, como chave para a promoção das cidades criativas. O trabalho ressalta que Lisboa representa uma das 25 melhores cidades para se viver no mundo. Tal posição se deve à crescente atividade cultural presente em Lisboa, impulsionada por caracterizar um destino cultural, com museus importantes e espaços urbanos preservados e históricos. Porém, o autor conclui que é necessário a flexibilização na burocracia em Lisboa, especialmente no incremento da sua dinâmica, e na otimização da mobilidade urbana, fatores importantes para a atração de pessoas e empresas.

Melguizo (2011) relata a experiência de Medellin, segunda maior cidade da Colômbia. Medellin, em 1991, era a cidade mais violenta do mundo, associada às drogas e à violência. Atualmente, Medellin reduziu o número de mortes violentas em 10\%, em relação ao ano de 1991, em virtude da transformação cultural (MELGUIZO, 2011). O autor relata que a cidade acreditou na mudança política e o processo ocorreu por meio de um movimento cívico. A mudança proporcionada por ONGs, empresas e universidades, contribuiu para que o foco orçamentário fosse a educação e a cultura. As transformações em Medellin fizeram com que a cidade se tornasse um destino turístico, em que o forte incentivo público proporcionou uma mudança na programação cultural da cidade. Em suma, o turismo proporcionou que mais de 30 novos hotéis de 4 e 5 estrelas fossem abertos na cidade, além da geração de emprego e renda para a população (MELGUIZO, 2011).

Para o território nacional, o trabalho de Machado et al (2016) buscou identificar os empreendimentos relacionados à economia criativa e à economia popular e solidária na Região Metropolitana de Belo Horizonte (RMBH). O trabalho identificou a existência de uma concentração em Belo Horizonte de artes plásticas e escritores. Brumadinho, por exemplo, teve concentração de artes plásticas e performáticas e outros resultados evidenciaram a concentração de diferentes segmentos em diferentes municípios ${ }^{1}$. Sobre a RMBH, concluiuse que a presença de autônomos e pequenas empresas do setor criativo na região promoveu o crescimento na contratação nos setores relacionados ao turismo e cultura. No entanto, não foi verificado nenhum tipo de apoio para as cadeias de produção gastronômica e de artesanato. Como resultado, o trabalho ressaltou a importância da identificação de aglomerados produtivos voltados para a produção criativa e de base popular e solidária.

Em relação à região metropolitana de São Paulo, Vieira, Santos e Carniello (2012) investigaram que o município de Taubaté empregava, em 2012, 1.682 trabalhadores criativos, metade deles nas áreas de arquitetura e engenharia, com dados menos expressivos para as áreas culturais. Para o estudo, os autores elaboraram uma análise exploratória de dados para 14 segmentos da economia criativa ${ }^{2}$. Vieira Santos e Carniello (2012) identificaram que Taubaté possui uma importância cultural e histórica, mas o número de trabalhadores formais na área criativa é irrisório. Tal resultado pode ser associado à informalidade muito presente no setor criativo e que dificulta mensurar o real tamanho do mercado de trabalho do setor. Em suma, o estudo apontou a carência de investimentos para o segmento criativo, destacando o potencial para o crescimento e diversificação da economia da região. (VIEIRA, SANTOS e CARNIELLO, 2012).

Por sua vez, Reis (2011) utilizou exemplos de projetos de sucesso e as possibilidades de crescimento derivados do investimento em economia criativa. $O$ trabalho apresentou diversos casos em que a criatividade obteve êxito em fomentar o desenvolvimento urbano. A autora retrata como a inovação influência no resultado de mudança de olhares e, do mesmo modo, como as cidades criativas estão em constante estado de busca por algo novo e interessante, o que a permite estar em constante estado de transformação, embora a inovação e a criatividade sejam independentes do tamanho da cidade (REIS, 2011).

Além da inovação, Reis (2011) afirma que as cidades criativas possuem fortes conexões, tanto no sentido da mobilidade urbana quanto no intercâmbio de ideias entre as diversas áreas de conhecimento existentes dentro da própria cidade. As cidades criativas também apresentam conexão com sua cultura. A conexão é representada como um conjunto de conteúdos de valor intangível e simbólico, que dialoga com as características particulares da cidade. O discurso também é análogo ao discurso de Landry (2004), que reforça a importância de a cidade utilizar sua cultura como forma de se destacar da homogenização do mundo globalizado.

Reis (2011) afirma que ofertas culturais têm alta capacidade de mobilizar os habitantes. O Centro Cultural do banco do Brasil, por exemplo, atrai uma audiência de todos os lugares de São Paulo. Ademais, equipamentos culturais podem gerar efeitos multiplicadores, incentivando pequenos comércios, bares,

1 O município de Florestal possuía alta concertação de artes performáticas, enquanto Itatiaiçu tinha concertação de artes plásticas e artesanato, destaque para Taquaraçu de Minas possuía concentração de artesanato assim como Juatuba.

2 Expressões culturais (artesanato, festas populares, folclore, museus, bibliotecas); artes cênicas (criação artística, espetáculos); artes visuais (criação artística, ensino de arte, museus e galerias); música (criação, produção, shows); filme e rádio (desenvolvimento de sets, produção, fotografia, exibição); TV e rádio (produção, transmissão); mercado editorial (edição de livros e jornais, edição digital). 
restaurantes, entre outros pontos que geram dinamismo local como o exemplo da Pinacoteca de São Paulo, que dialoga intimamente com seu entorno (REIS, 2011).

As estruturas artísticas permitem novas formas de lidar com problemas estruturais urbanos, um exemplo é a cidade de Bogotá, que através de uma política de "cultura cidadã", estabeleceu projetos para que a cidade fosse apropriada pela população, o exemplo mais famoso é o dos mímicos que repreendiam de maneira recreativa e irônica os motoristas que não respeitavam as faixas de pedestres (REIS, 2011).

Sobre a cidade de São Paulo, Oliveira et al (2015) realizaram um levantamento teórico acerca dos conceitos da economia criativa e das cidades criativas e aplicaram esses conceitos analisando o caso de Paulínia (SP) e o seu Polo Cinematográfico. Os conceitos de capital social, capital humano e capital criativo ${ }^{3}$ são analisados de acordo com a aplicação do programa municipal. A cidade de Paulínia se encontra no interior do estado de São Paulo e, para o período, possuía 82.146 habitantes (IBGE), de acordo com o Censo Demográfico de 2010. O município apresentava o $13^{\circ}$ melhor IDH do estado em 2015 e possuiu um dos 25 melhores PIB per capita do país, fruto da economia do município baseada nas refinarias de petróleo já instaladas.

Os autores discutem como o alto IDH da cidade influenciou positivamente o capital. Além disso, observou-se que o desenvolvimento do capital cultural foi feito pela implementação de escolas da área audiovisual - Escola Magia do Cinema - e festivais como A Mostra Magia do Cinema e o Festival de Cinema de Paulínia (OLIVEIRA et al., 2015).

Entretanto, a instabilidade das instituições e dos órgãos governamentais impossibilitou a continuidade dos projetos. Os festivais foram cancelados algumas vezes e as escolas especializadas encerraram suas atividades durante o período sob estudo. Por fim, mesmo existindo investimento inicial, dada a fragilidade do capital institucional, todos os outros capitais foram atingidos indiretamente e, sob essa circunstância, não foi possível mensurar o potencial que tal investimento cultural poderia ter na cidade (OLIVEIRA et al., 2015).

Sobre o setor criativo, o trabalho de Nyko e Zendron (2018) explora as características do referido setor no Brasil. Os autores apontam que o crescimento do setor a nível nacional tende a permanecer acima do crescimento mundial e, especificamente no Brasil, existe um potencial ainda maior devido a seu vasto mercado interno e sua riqueza cultural diversa. Nyko e Zendron (2018) retornam ao problema da incerteza da demanda apresentado por Caves (2000) e relatam que as empresas mitigam tal incerteza com a diversificação de seus portfólios ou produzem bens e serviços com experiências já conhecidas e consagradas pelos consumidores. Outro aspecto relevante do setor é a intangibilidade dos ativos gerados, a propriedade intelectual que possui potencial para geração de receita por longos períodos e os ciclos longos de produção ${ }^{4}$. Tais aspectos geram dificuldades de financiamento dado a natureza da própria indústria criativa (NYKO e ZENDRON, 2018).

De acordo com a discussão da literatura do trabalho, a definição de cidades criativas será representada por microrregiões criativas brasileiras. Como o objetivo é utilizar indicadores para mapear as microrregiões criativas no Brasil, será adotado o conceito de Reis e Urani (2011) que caracterizam o espaço criativo como aquela que possui três elementos: inovação (tecnológica, social e cultural); conexões (de nível histórico, diversidade); e cultura (expressa em bens, serviços, patrimônio, presença de indústrias criativas, ambientes criativos). Além dessa definição, o conceito de Florida (2004) acerca dos 3 T's - tolerância, talento, tecnologia - necessários para a classe criativa ser atraída para a cidade também será utilizada para a delimitação dos indicadores representados no trabalho. A seguir, no quadro 1, observa-se a síntese comparativa entre os trabalhos analisados no referencial empírico, de acordo com suas especificidades.

\section{3-Metodologia e base de dados}

\section{1- Análise de Componentes Principais (ACP) e Análise Exploratória de Dados Espaciais (AEDE)}

O presente trabalho utilizará duas metodologias. A primeira, a análise de componentes principais, tem por objetivo caracterizar e identificar o perfil da criatividade no território brasileiro, entre as 558 microrregiões do Brasil (IBGE) como unidades de observações. Por se tratar de um conjunto de variáveis que abrangem

3 Capital social: o crescimento depende de laços fortes de comunidades; capital humano: as pessoas são o principal impulso para o desenvolvimento; e capital criativo: teoria de Florida (2004) em que a classe criativa gera o desenvolvimento econômico

4 A produção de um jogo, por exemplo, pode durar mais de três anos, além desse ciclo longo também há a incerteza da demanda e da experiência do consumidor. 
desde a infraestrutura (museus, galerias) até informações sobre emprego, é oportuno elaborar componentes que sintetizem as informações relevantes para o mapeamento das cidades criativas no Brasil. Para tal, é necessário utilizar de um método específico de análise multivariada, a análise de componentes principais (ACP) HONGYU et al, 2015).

A técnica da ACP modela a estrutura de covariância, agrega um conjunto de varáveis correlacionadas (número de designers e número de faculdades de design, por exemplo) e, por meio de transformações lineares, reduz a quantidade de variáveis para um número menor de variáveis não correlacionadas, mas que contém a maioria das informações do conjunto inicial, o processo é feito redistribuindo a variação observada na matriz de dados original (MANLY,1986). O principal objetivo do método é reduzir os dados para criar um conjunto de novas variáveis (ou um índice) para substituir o conjunto original com a menor perda de informação possível, essas variáveis de mesma dimensão são os componentes principais (HONGYU et al, 2015).

Uma matriz de dados, inicialmente com $p$ variáveis, pode ser caracterizada por $p$ componentes principais bem como representada por $k$ componentes principais sendo $k<p$. O objetivo do presente trabalho é sintetizar as principais informações do conjunto de dados em um índice, sendo assim utilizar o método de forma que o $k$ seja menor que o número de variáveis inicial. A análise de componentes principais é capaz de estabelecer um índice a partir da combinação linear dos dados de uma matriz, definindo peso para ponderar as variáveis (HONGYU et al, 2015).

Os componentes principais são obtidos por meio da diagonalização, ou seja, por meio do cálculo de autovalores e autovetores, de uma matriz simétrica positiva. As vantagens do método da ACP incluem retirar a multicolinearidade presente nas variáveis, transformando um conjunto de variáveis intercorrelacionadas em um novo conjunto não relacionadas, ou seja, o método reduz as variáveis a eixos ortogonais (perpendiculares) que representam algumas variáveis, alinhando a variação dos dados de forma decrescente. O método possui pontos fracos pois é sensível a outliers, sendo não recomendado quando se tem uma matriz com muitos zeros ou dados ausentes (HOGYU et al, 2015).

Em suma, o método de ACP será utilizado para a geração de componentes da criatividade das microrregiões, que sintetizem as informações das especificadas tipologias.

Em relação a segunda metodologia, será apresentado a seguir o método de análise exploratória de dados espaciais (AEDE), que será aplicado após a criação dos perfis indicados pela ACP.

A análise exploratória de dados espaciais busca mapear os agrupamentos (clusters) significativos de microrregiões criativas no Brasil. Nesse caso, pretende-se observar quais microrregiões apresentam o perfil de cidades criativas e buscar padrões de associações espaciais (clusters espaciais), regimes espaciais ou outras formas de instabilidade espacial (não - estacionariedade). AAEDE representa uma série de técnicas de análise estatística que possibilita descobrir padrões espaciais contidos nos dados, permitindo, assim, a identificação de agrupamentos e distribuições espaciais (ALMEIDA, 2004). Para ser viável, é importante que se utilize variáveis densas, ou seja, variáveis que podem ser divididas por indicadores de intensidade - variáveis per capita ou por área, por exemplo. A análise consiste na observação de eventos, se eles apresentam algum tipo de padrão sistemático ou se estão distribuídos aleatoriamente no espaço. Ademais, com a aplicação da AEDE, é possível extrair medidas de autocorrelação espacial e autocorrelação local a fim de identificar a influência dos efeitos espaciais por intermédio de instrumentos quantitativos e não somente pela examinação de mapas.

Almeida (2004) descreve que o primeiro passo para a AEDE é o teste da hipótese de que os dados espaciais são aleatoriamente distribuídos, essa aleatoriedade espacial significa que os valores de uma região - quantidade de infraestrutura criativa, por exemplo - não dependem de valores atribuídos a regiões vizinhas. O oposto disso seria a autocorrelação espacial, a existência de autocorrelação espacial nos indica coincidência de similaridade de valores de um atributo com a similaridade de localização desse atributo, de tal modo, podemos testar a hipótese nula de aleatoriedade espacial (ALMEIDA,2004).

A estatística $I$ de Moran, proposta em 1948, é um coeficiente de associação linear. Nele temos dois termos, o primeiro diz sobre a variância dos dados de interesse $\Sigma\left(y_{i}-\bar{y}\right)^{2}$, o segundo termo fornece a ideia da configuração espacial dos dados $n \Sigma \Sigma w_{i j}$.

$$
I=\frac{n}{\Sigma \Sigma w_{i j}} \frac{\Sigma \Sigma w_{i j}\left(y_{i}-\bar{y}\right)\left(y_{j}-\bar{y}\right)}{\Sigma\left(y_{i}-\bar{y}\right)^{2}}
$$

A equação (2.1), onde n é o número de unidades espaciais, $y_{i}$ é a variável de interesse, $w_{i j}$ é o peso espacial para o par de unidades $i$ e $j$. Assim, a estatística $I$ de Moran "é baseada nas somas de produtos cruzados de $y_{i}$ para regiões vizinhas, dado pela matriz de pesos espaciais W" (ALMEIDA, 2004). Essa matriz de pesos espaciais $\mathrm{W}$ é apresentada a seguir.

A matriz de pesos espaciais é construída com a ideia de contiguidade, ou seja, duas regiões são vizinhas se elas compartilharem uma fronteira física comum. Se duas regiões forem vizinhas, atribui-se o valor unitário (1), caso não sejam, atribui-se o valor nulo (0). 
Tal conceito de vizinhança pode parecer simples num primeiro momento, mas existem várias maneiras de se definir vizinhança com diferentes definições do próprio conceito de contiguidade. Almeida (2004) relata que o problema reside na definição do conceito de fronteira geográfica por meio de mapas que são meras abstrações. É possível definir a convenção de contiguidade como rainha (queen) ou como torre (rook), a definição de rainha assume maior número de vizinhos pois considera qualquer ponto (nó) de contato, enquanto a torre exige um contato entre regiões diferente de zero.

O valor esperado para o $I$ de Moran é de -[1/(n-1)], ou seja, o valor se não houvesse padrão espacial nos dados, os valores que excedem esse valor esperado indicam autocorrelação espacial positiva - indicando similaridade entre valor do atributo estudado e da localização -, valores abaixo do valor esperado indicam autocorrelação negativa - indicando uma dissimilaridade entre valor do atributo estudado e da localização (ALMEIDA, 2004).

Pode-se agora analisas padrões de associação espacial, porém, quando temos indicação de presença de forte indicação de autocorrelação global, isso pode camuflar padrões locais de agrupamento (clusters). Sendo assim, as estatísticas de autocorrelação global não possuem capacidade de identificar a ocorrência de autocorrelação local, para isso, usamos o $I$ de Moran local. $\mathrm{O} I$ de Moran local captura padrões de associação linear e decompõe o indicador global de autocorrelação em quatro categorias. Intuitivamente pode-se interpretar o $I$ de modo que ele indique o grau de agrupamento dos valores similares de uma determinada observação, identificando clusters espaciais significantes do ponto de vista estatístico (ALMEIDA, 2004).

Se o valor do coeficiente for positivo, existem evidências de autocorrelação espacial positiva, caso seja negativo, há evidências de autocorrelação espacial negativa. Almeida (2004) relata que o diagrama de dispersão de Moran fornece 4 tipos de associações espaciais. Os agrupamentos podem ser Alto-Alto (AA) valores altos da variável de interesse com unidade espaciais ao redor que também apresentam valores altos -, Baixo-Baixo (BB) - valores baixos da variável de interesse cercado de unidades com valores também baixos -, Alto-Baixo (AB) - representa um cluster com alto valor da variável de interesse cercado de regiões de baixo valor - e Baixo-Alto (BA) - um cluster com um baixo valor da variável de interesse cercada de unidades com alto valor. A partir desse diagrama, é possível observar os resultados em um mapa de dispersão de Moran. Essa mesma análise pode ser feita para uma dispersão multivariada onde a nova inclinação do diagrama seria: $b=\frac{X^{\prime} W y}{X^{\prime} X}$

\section{2- Base de dados e descrição das variáveis}

Como mencionado na introdução, o presente trabalho tem por objetivo analisar o perfil espacial das microrregiões criativas brasileiras, por intermédio da análise exploratória de dados espaciais (AEDE). Além disso, será investigado quais cidades brasileiras apresentam maior ou menor dinamismo criativo, de acordo com suas características. A partir das metodologias apresentadas, a análise de clusters para as microrregiões criativas brasileiras permitirá explorar as possíveis associações espaciais que, porventura, possam existir. O recorte temporal utilizado na pesquisa, isto é, os anos entre 2015 a 2019, foram selecionados de acordo com a disponibilidade dos dados, considerando-se o caráter contemporâneo das informações sobre as microrregiões brasileiras.

Dessa forma, a presente seção destaca as informações necessárias para a construção da tipologia das características das microrregiões criativas brasileiras. A base de dados foi composta por diversas fontes permitindo, portanto, a construção de indicadores (proxies) baseados na literatura da área, conforme explicitado a seguir:

\section{Dimensão de educação e tecnologia}

- Variável educação

A variável educação foi composta com base nas notas obtidas no ano de 2017, por intermédio do Índice de Desenvolvimento da Educação Básica (IDEB). A inclusão da variável sobre educação é necessária pois as indústrias criativas são empresas que produzem e distribuem bens e serviços, utilizando o capital intelectual e a criatividade como matérias-primas (COSTA, SOUZA-SANTOS, 2011). Melguizo (2011) também destaca a importância da educação quando descreve o caso de sucesso da cidade de Medellin. A partir dos investimentos na área da educação, a cidade conseguiu reverter e minimizar os problemas urbanos e sociais. 
A variável tecnologia foi investigada somando o número de patentes de programa de computadores e patentes de propriedade intelectual nos anos de 2015, 2016 e 2017, de acordo com o Instituto Nacional de Propriedade Intelectual (INPI). Tanto as variáveis de educação quanto a de tecnologia promovem o talento nos centros criativos. Ademais, a dupla causalidade entre o desenvolvimento urbano e o desenvolvimento artístico-cultural ocorrem quando há desenvolvimento regional, tornando as pessoas mais escolarizadas (FLORIDA (2004); BILLIE e SCHULZE (2006)).

\section{Dimensão Cultural}

- Variável locais culturais

A variável sobre os locais culturais tem por objetivo identificar grupos sem fins lucrativos de natureza cultural nos quais desenvolvem atividades culturais em suas comunidades e territórios. Os locais culturais fazem parte da Política Nacional de Cultura Viva ${ }^{5}$ e estão listados no site do programa Cultura Viva. De acordo com a literatura, Bille e Schulze (2006) argumentam que alguns dos efeitos da "força cultural" como caminho de regeneração urbana, incluem a presença de arte e cultura nas regiões, em que tornam o seu valor mais atrativo para pessoas e empresas. Nessa concepção, Reis (2011) ressalta que as cidades criativas apresentam conexão com sua cultura, representada como um conjunto de conteúdos de valor intangível e simbólico, em que dialoga com as características particulares daquela região.

- Variável de intensidade criativa

A inclusão da variável sobre a classe criativa - denominado como a variável intensidade criativa segue a classificação mencionada na revisão da literatura (seção 2.1). Dessa forma, será analisada a força de trabalho nas áreas consideradas criativas (Anexo 1) bem como trabalhadores de áreas ligadas a qualidade de vida e ambiental (KAGEYAMA, 2011; LANDRY, 2008). Como salientado por Florida (2004), a presença da classe criativa é, atualmente, um fator de destaque para o desenvolvimento das cidades e regiões. Para o cálculo da variável, dividiu-se os números de trabalhadores criativos com os trabalhadores empregados em todas as áreas da CNAE 2.0.

- $\quad$ Variável de unidades locais criativas

A variável que representa as unidades locais criativas foi elaborada a partir do quantitativo de empresas e outras organizações, além de suas respectivas unidades locais formalmente constituídas, registradas no Cadastro Nacional de Pessoa Jurídica (CNPJ), disponibilizada pelo IBGE. As informações disponíveis referem-se às empresas e às unidades locais em que no ano de 2018 apresentaram-se ativas no cadastro, de acordo com o número de unidades locais por seção e divisão da classificação de atividades (CNAE 2.0), para os municípios com 50.000 habitantes ou mais.

- Variável de estabelecimentos criativos

Quanto a variável que abrange os estabelecimentos criativos, ela é representada pelos estabelecimentos cadastrados na RAIS, no ano de 2018, e se enquadram nos setores criativos ou ligados à atividade criativa bem como estabelecimento de áreas ligadas a qualidade de vida e ambiental 6 (KAGEYAMA, 2011; LANDRY, 2008). É relevante destacar que, ao contrário da variável de unidades locais criativas, a variável de estabelecimentos criativos abrange um maior número de cidades em que se incluiu os municípios com menos de 50.000 habitantes.

- $\quad$ Variável turismo

A variável proxy para o setor de turismo considera as agências de turismo cadastradas no Cadastrur (Ministério do Turismo) no ano de 2018, bem como os prestadores de serviços turísticos e hotéis cadastrados no Cadastrur. A respectiva variável foi dividida pelo total da população da microrregião. A justificativa para o uso da variável é representada pela sua importância do setor do turismo para as cidades criativas. Por exemplo, o respectivo setor proporcionou a reconstrução da cidade de Medellín e que criou diversos empregos diretos e indiretos ligados ao turismo, bem como diversos subsetores que foram beneficiados por ele (MELGUIZO, 2011). O turismo tem um grande papel na região criativa pois é uma maneira de atrair pessoas, comércio, serviços e insumos intangíveis da região como o resgate do folclore, promoção das festas populares, as paisagens, as crenças e as tradições locais. (KAGEYAMA, 2011; LANDRY, 2008; MELGUIZO, 2011; REIS, 2011; STRICKLAND, 2011).

5 Cultura Viva - Rede de Incentivo e Disseminação de Iniciativas Culturais

6 Foram utilizadas as mesmas classificações que foram utilizadas para a variável de unidades locais 
- Variável cultural

A variável proxy para a cultura mensura a infraestrutura cultural por meio da quantidade de salas de cinema, teatros e museus com base nos dados da ANCINE e da FUNARTE, para o ano de 2019. Além disso, a variável também inclui o número de bandas, orquestras, escolas de música e espaços musicais registrados na FUNARTE, no ano de 2018. A justificativa para o uso da variável supracitada tem como base a representação das microrregiões. Uma vez que estas se tornam criativas por meio de atividades culturais diversas, podendo ser por intermédio de várias manifestações culturais como: exposições de obras de arte públicas, bares e apresentações de bandas (KAGEYAMA, 2011; MELGUIZO, 2011).

\section{Dimensão econômico-financeira}

- Variável instituições financeiras

A variável sobre as instituições financeiras representa as instituições financeiras representadas no IBGE, no ano de 2018. A existência de instituições financeiras numa determinada microrregião indica um facilitador para operações financeiras de empréstimo, de vendas e de compras. As microrregiões criativas podem, por exemplo, receber investimentos para determinados projetos como parques, transporte (LIN, 2011) Também vale ressaltar que no ambiente da economia criativa existe uma forte presença de micro e pequenas empresas que buscam o acesso a crédito, onde é necessária a presença dessas instituições (BARRETTO, 2011; REIS, 2011; NYKO e ZENDRON, 2018).

- Variável desenvolvimento

A variável proxy para o desenvolvimento foi construída com base no produto interno bruto (PIB) per capita das microrregiões, no ano de $2017^{7}$. As cidades (representadas espacialmente pelas microrregiões) criativas utilizam ativos intangíveis relacionados à arte, cultura e criatividade para superar problemas e gerar desenvolvimento local e regional, tanto de maneira direta como por externalidades geradas pelo incentivo à cultura na região (BILLE, SCHULZE, 2006; LANDRY, 2011; MELGUIZO, 2011; REIS, 2011). A economia criativa se mostra como um dos setores mais dinâmicos e com maior potencial para o crescimento de renda e a geração de empregos atualmente. Tal efeito é diretamente ligado à produção da região e, consequentemente, ao desenvolvimento (BARRETTO, 2011; UNCTAD/DITC/TED, 2018).

- Variável de densidade populacional

A variável que mensura a densidade populacional foi construída a partir da divisão da população na microrregião no ano de2019, pela extensão territorial da microrregião $\left(\mathrm{km}^{2}\right)$. De acordo com a literatura, as cidades criativas possuem melhores resultados econômicos quando densas. Porém, não há um consenso quanto ao tamanho populacional, nem mesmo ao tamanho da cidade (BILLIE E SCHULZE, 2006; FLORIDA, 2004; LANDRY, 2008; REIS, 2011).

\section{Dimensão seguranca}

- Variáveis juventude perdida e homicídios

A análise sobre a dimensão segurança incluiu duas variáveis de crime. Os dados foram extraídos do Atlas da Violência do IPEA. A variável de homicídio representa os homicídios para o ano de 2017, enquanto a variável juventude perdida incluiu apenas os homicídios de pessoas entre 15 a 29 anos, para o período de 2016. A justificativa para o uso das variáveis é representada por regiões criativas que apresentam índices de criminalidade significativos, mesmo apresentando os efeitos positivos da economia criativa (KAGEYAMA, 2011; LANDRY, 2008; REIS, 2011).

Para melhor visualização da síntese dos dados a serem utilizados, o Quadro 1 apresenta a descrição das variáveis de acordo com o referencial teórico e fonte de dados. Antes da análise dos resultados, foram calculadas estatísticas descritivas das variáveis, assim como a matriz de correlação. Os resultados encontram-

$7 \mathrm{O}$ ano base utilizado foi o ano de 2010 usando um deflator de 1.539, calculado com base no Índice de Preços ao Consumidor (IPCA). 
se listados nos Anexos 1 e $2^{8}$. A matriz de correlação contribui para verificar se há algum caso de autocorrelação entre as variáveis usadas na Análise de Componentes Principais (ACP).

Quadro 1 - Descrição das variáveis para as microrregiões brasileiras

\begin{tabular}{|c|c|c|}
\hline Dimensão de Educação e Tecnologia & Fonte & Ano \\
\hline Educação (educ) & INEP & 2017 \\
\hline Tecnologia (tec) & INPI & 2015,2016 e $2017^{9}$ \\
\hline Dimensão Cultural & Fonte & Ano \\
\hline Pontos de Cultura ( $\left.p t s \_c u l t\right)$ & Cultura Viva & 2020 \\
\hline Intensidade Criativa (intens_criat) & RAIS & 2018 \\
\hline Unidades Locais Criativas (cempre) & IBGE & 2018 \\
\hline Estabelecimentos Criativos (est_criat) & RAIS & 2018 \\
\hline Turismo (tur) & Cadastur & 2018 \\
\hline Cultura (cult) & ANCINE/FUNARTE & 2018 e $2019^{10}$ \\
\hline Dimensão Econômica Financeira & Fonte & Ano \\
\hline Instituições Financeiras (inst_financ) & IBGE & 2018 \\
\hline Produto Interno Bruto ( $p i b)$ & IBGE & 2017 \\
\hline Densidade Populacional (densidade) & IBGE & 2017 \\
\hline Dimensão de Segurança & Fonte & Ano \\
\hline Homicídios de 15 a 29 anos (juv_perd) & IPEA & 2016 \\
\hline Homicídios (homic) & IPEA & 2017 \\
\hline
\end{tabular}

Fonte: elaboração própria com base nos dados do IBGE, IPEA, INEP, INPI, RAIS, Cultura viva, Ancine e Funarte

\section{4- Resultados}

Como forma de caracterizar as 558 microrregiões brasileiras por intermédio das 13 variáveis escolhidas originalmente (vetor aleatório original), será apresentado em primeiro lugar, os resultados da Análise de Componentes Principais (ACP). O Quadro 2 reúne os resultados obtidos da ACP com base nas variâncias percentuais de cada uma das variáveis.

8 As atividades informais presentes nas atividades criativas (VIEIRA, SANTOS e CARNIELLO, 2012) não puderam ser observadas e incluídas na base de dados,

9 Dados somando os números para os 3 anos uma vez que a inovação tecnológica, medida por meio das patentes, é disruptiva e não tão frequente quanto os demais dados. Assim, as patentes de apenas um ano contém muito muitos zeros e números muito pequenos.

10 Dados para quantidade de salas de cinema, teatros e museus de acordo com dados da ANCINE e da FUNARTE para o ano de 2019, número de bandas, orquestras, escolas de música e espaços musicais registrados na FUNARTE em 2018. 


\section{Quadro 2- Variância percentual explicada pela Análise de Componentes Principais (ACP)}

\begin{tabular}{|c|c|c|}
\hline \multirow{2}{*}{ Componentes } & \multicolumn{2}{|c|}{ Variância explicada } \\
\hline & Individual & Acumulada \\
\hline Componente 1 & 0.2986 & 0.2986 \\
\hline Componente 2 & 0.1435 & 0.4421 \\
\hline Componente 3 & 0.1067 & 0.5488 \\
\hline Componente 4 & 0.1001 & 0.6489 \\
\hline Componente 5 & 0.0649 & 0.7137 \\
\hline Componente 6 & 0.0599 & 0.7736 \\
\hline Componente 7 & 0.0537 & 0.8273 \\
\hline Componente 8 & 0.0516 & 0.8789 \\
\hline Componente 9 & 0.0396 & 0.9185 \\
\hline $\begin{array}{l}\text { Componente } \\
10\end{array}$ & 0.0335 & 0.9520 \\
\hline $\begin{array}{l}\text { Componente } \\
11\end{array}$ & 0.0239 & 0.9760 \\
\hline 12 & 0.0126 & 0.9886 \\
\hline 13 & 0.0114 & 1.0000 \\
\hline
\end{tabular}

Fonte: elaboração própria com base no STATA 10.

O componente 1 é representado por $29,86 \%$ da variabilidade total dos dados. O segundo componente responde por $14,35 \%$ dessa variabilidade, o terceiro componente responde por $10,67 \%$ e o quarto por $10,01 \%$ da variância dos dados. Apesar de tradicionalmente optar-se por um número mínimo de componentes que representem 70\% da variância total (Johnson e Wichern, 1998 apud Hongyu et al, 2015), optou-se apenas pelos 4 primeiros componentes - responsáveis por $64,89 \%$ da variância total - pois o componente seguinte, o $5^{\circ}$ componente, tem peso inferior a $10 \%$ (apenas $6,49 \%$ na variância total dos dados).

Com o intuito de analisar as configurações, observa-se no Quadro 2 que o componente 1 caracteriza microrregiões com baixa criminalidade, alta concentração de empresas/unidades criativas e trabalhadores criativos, alto desenvolvimento e educação. Tais resultados são pertinentes devido a associação desses fatores como sendo características dos "centros criativos" (FLORIDA, 2004). Algumas capitais brasileiras ${ }^{11}$ se enquadraram neste componente, tais como Belo Horizonte, Brasília, São Paulo e Curitiba. É oportuno ressaltar que as microrregiões apresentadas no componente são concentradas, com exceção de Brasília e Campo Grande, no sul e sudeste do Brasil, indicando uma concentração geográfica dos centros criativos nas regiões que, historicamente, possuem maior desenvolvimento econômico.

Ademais, constatou-se que regiões caracterizadas no componente 1 são polos universitários, como por exemplo, Lavras, Barbacena, São João Del Rei, Juiz de Fora e São José dos Campos (onde Taubaté está inserida, em concordância com o trabalho de Vieira, Santos e Carniello, que ressaltou o potencial criativo que a cidade possuía no ano de 2012); e regiões com maior concentração de indústrias (Santos, Itabira, Ubá, Muriaé, e várias microrregiões do estado de São Paulo). As microrregiões supracitadas também apresentaram uma menor magnitude de locais culturais comparando-se aos estabelecimentos culturais, uma vez que tais regiões aparentam ser mais focadas nas atividades lucrativas das indústrias criativas (Caves, 2000) alinhadas à presença da "classe criativa" (FLORIDA, 2004).

11 Tabelas com as microrregiões e os componentes que tendem a se enquadrar no anexo 2. 
Sobre o componente 1, foi unânime o grande peso da variável educação. Mais especificamente, por apresentarem o fator da educação de qualidade, a dupla causalidade entre desenvolvimento urbano e desenvolvimento artístico-cultural é mais evidente nessas regiões, onde se concentram pessoas com mais escolaridade (BILLIE e SCHULZE, 2006). Deste modo, as microrregiões representadas pelo componente 1 também são chamadas de Microrregiões Criativas e Desenvolvidas (Quadro 3).

Quanto ao segundo componente, observou-se que existe um efeito superior sobre as microrregiões quanto ao aspecto da elevada criminalidade, da baixa qualidade de educação, da pouca presença cultural e de uma alta densidade populacional. No entanto, as respectivas microrregiões com essa característica apresentaram elevados números de trabalhadores criativos e de empresas criativas, nos quais 19 das 27 capitais do Brasil são caracterizadas por este componente. Como exemplo de microrregiões com capitais brasileiras que se situam nesse componente podemos citar: Rio de Janeiro, Vitória, Fortaleza e Natal, que historicamente são lugares destacados pela criminalidade elevada e pela presença do processo de favelização e marginalização. Desta forma, o segundo componente foi denominado como sendo representado por Microrregiões densas e violentas.

\section{Quadro 3 - Caracterização das variáveis nos 4 primeiros componentes principais}

\begin{tabular}{|l|l|l|l|l|}
\hline \multirow{2}{*}{ Variáveis } & \multicolumn{4}{c|}{ Componentes } \\
\cline { 2 - 5 } & $\begin{array}{l}\text { 1. } \\
\text { Microrregiões } \\
\text { Criativas e } \\
\text { desenvolvidas }\end{array}$ & $\begin{array}{l}\text { 2. } \\
\text { Microrregiões } \\
\text { densas e } \\
\text { violentas }\end{array}$ & $\begin{array}{l}\text { 3. } \\
\text { Microrregiões } \\
\text { com potencial } \\
\text { turístico }\end{array}$ & $\begin{array}{l}\text { 4. Microrregiões } \\
\text { com dinamismo } \\
\text { cultural e } \\
\text { tecnológico }\end{array}$ \\
\hline Educação & $\mathbf{0 . 2 6 9 1}$ & -0.1388 & -0.0996 & -0.0004 \\
\hline Tecnologia & $\mathbf{0 . 3 1 0 2}$ & 0.0882 & -0.2547 & $\mathbf{0 . 3 7 5 7}$ \\
\hline Pontos de Cultura & 0.0408 & -0.1411 & 0.0652 & $\mathbf{0 . 6 5 9 8}$ \\
\hline Intensidade Criativa & $\mathbf{0 . 3 3 7 1}$ & 0.2570 & $\mathbf{0 . 2 0 9 4}$ & -0.0925 \\
\hline $\begin{array}{l}\text { Unidades } \\
\text { Criativas }\end{array}$ & 0.3013 & 0.2806 & -0.3740 & 0.1112 \\
\hline $\begin{array}{l}\text { Estabelecimentos } \\
\text { Criativos }\end{array}$ & $\mathbf{0 . 4 1 4 1}$ & 0.1184 & $\mathbf{0 . 3 0 0 5}$ & -0.1891 \\
\hline Turismo & 0.2557 & 0.0851 & $\mathbf{0 . 5 3 8 2}$ & 0.0499 \\
\hline Cultura & 0.2550 & -0.1180 & 0.1843 & $\mathbf{0 . 4 9 7 0}$ \\
\hline Instituições Financeiras & $\mathbf{0 . 3 4 9 6}$ & -0.0645 & 0.1298 & -0.2535 \\
\hline Produto Interno Bruto & 0.3216 & 0.1641 & -0.2776 & -0.1496 \\
\hline Densidade Populacional & 0.0820 & $\mathbf{0 . 3 2 8 0}$ & -0.4090 & -0.0026 \\
\hline $\begin{array}{l}\text { Homicídios de 15 a } 29 \\
\text { anos }\end{array}$ & -0.2114 & $\mathbf{0 . 5 8 4 8}$ & 0.1636 & 0.1446 \\
\hline Homicídios & -0.2463 & $\mathbf{0 . 5 4 0 8}$ & 0.1880 & 0.0993 \\
\hline
\end{tabular}

Fonte: elaboração própria com base no STATA.

Entretanto, as microrregiões do segundo componente possuem relação positiva com variáveis de intensidade criativa e empresas criativas, o que indica que os setores criativos não são enfraquecidos mesmo em microrregiões com deseconomias de aglomeração. Deste modo, as regiões caracterizadas pelo segundo componente desfrutam dos efeitos de longo prazo que a cultura promove ao desenvolvimento das regiões, tais como um ambiente artístico e cultural atrativo para pessoas e empresas (BILLIE, SCHULZE, 2006). Porém, tais microrregiões, possuem problemas aprofundados pela desigualdade social e econômica no Brasil, especialmente no aspecto social.

Em relação ao terceiro componente, ele é caracterizado por microrregiões com pouca magnitude na qualidade de educação e na questão tecnológica, sendo que nenhuma capital brasileira se enquadrou nesse 
componente. As microrregiões desse componente destacaram-se pelo elevado peso do setor de turismo, baixa densidade populacional e pouco desenvolvimento, sendo denominadas como Microrregiões com potencial turístico. Além disso, houve uma participação de microrregiões com pontos turísticos nacionais e parques de conservação ambiental encontrados em regiões como os Lençóis Maranhenses e a Chapada dos Veadeiros. Destaca-se também as microrregiões com força em suas tradições, folclore e produções artesanais como na microrregião de Salinas e produções familiares como na microrregião de Livramento de Brumado e Litoral de Camocim e Acaraú.

Ressalta-se que as microrregiões desse componente, em geral, concentraram cidades menores, menos populosas e mais tradicionais, isto é, baseiam-se em setores de serviços e geram renda sob a forma de trabalhos artesanais e informais. Como destacado por Melguizo (2011) no seu estudo para a cidade de Medellín, as pessoas buscam visitar a cidade para desfrutar de suas atrações e suas programações culturais em busca de conhecer e explorar novas culturas. $\mathrm{O}$ fato de pessoas demandarem o turismo de uma região, como foi o caso de Medellín, promovem empregos diretos ligados ao setor e ainda incentiva setores adjacentes (MELGUIZO, 2011). O turismo ainda se mostra capaz de estreitar as relações governamentais, as relações na comunidade e aumentar o alcance cultural de determinada região (STRICKLAND, 2011).

Por fim, o quarto componente abrange microrregiões com potencial cultural e tecnológico, e por isso, foram denominadas como Microrregiões com dinamismo cultural e tecnológico. Observou-se que a microrregião da capital do Piaú (Teresina) que se encontra nesse componente destaca-se pela produção na indústria. Ademais, a microrregião tem forte presença do artesanato e atividades culturais, abrigando também centros universitários e de pesquisa. Percebe-se, portanto, que as microrregiões caracterizadas pelo quarto componente possuem também possui polos educacionais de nível técnico e superior como em Diamantina, Floriano, Viçosa, Chapecó. Esse resultado amplia a discussão sobre as microrregiões criativas que possuem relações com atividades artesanais, culturais, ligadas às tradições e folclore. O contato com a cultura se expressa em eventos culturais bem como em locais históricos tradicionais como Sobral, Montes Claros, Guarabira. Logo, nesse contexto, é interessante ressaltar que apesar de o quarto componente apresentar pouca relevância nas áreas econômicas-financeiras, em comparação com as microrregiões do componente 1, a presença de polos de ensino no interior do Brasil e sua interação com a tecnologia e a presença cultural possuem reflexo regionais significativos, tanto nas microrregiões onde estão concentradas, quanto nas microrregiões vizinhas (LANDRY, 2004; REIS, 2011). Os reflexos de transbordamentos, também chamados de spillovers, serão investigados a seguir, por intermédio da análise exploratória de dados espaciais (AEDE).

A análise exploratória de dados espaciais (AEDE) permitiu identificar e explorar características espaciais das variáveis utilizadas e sumarizadas por meio da análise de componentes principais. Dessa maneira, a AEDE foi utilizada com o objetivo de observar quais microrregiões concentram espacialmente o perfil de microrregiões criativas. Além disso, buscou-se analisar e identificar os padrões de associações espaciais (clusters espaciais), regimes espaciais ou outras formas de instabilidade espacial (nãoestacionariedade) (Quadro 4).

Como ponto de partida para a AEDE, aplicou-se o teste de $I$ de Moran (Quadro 4) que, como especificado na seção metodológica, examina se os dados espaciais são aleatoriamente distribuídos, ou seja, se os valores de uma microrregião não dependem de valores atribuídos a microrregiões vizinhas. O oposto disso seria a autocorrelação espacial, a existência de autocorrelação espacial nos indica coincidência de similaridade de valores de um atributo com a similaridade de localização desse atributo, de tal modo, podemos testar a hipótese nula de aleatoriedade espacial (ALMEIDA,2004).

\begin{tabular}{|l|c|c|c|c|c|c|}
\hline & Quadro 4 - Índice de Moran para os 4 componentes identificados na ACP \\
\hline & I de Moran & E(I) & $\begin{array}{c}\text { Desvio } \\
\text { padrão }\end{array}$ & Média & $\begin{array}{c}\text { P } \\
\text { valor }\end{array}$ & Z valor \\
\hline $\begin{array}{l}\text { 1. Microrregiões criativas e } \\
\text { desenvolvidas }\end{array}$ & 0,7483 & $-0,0018$ & 0,0281 & $-0,0040$ & 0,001 & 26,681 \\
\hline $\begin{array}{l}\text { 2. Microrregiões densas e } \\
\text { violentas }\end{array}$ & 0,3775 & $-0,0018$ & 0,0382 & $-0,0028$ & 0,001 & 9,9423 \\
\hline $\begin{array}{l}\text { 3. Microrregiões com potencial } \\
\text { turístico }\end{array}$ & 0,2971 & $-0,0018$ & 0,0282 & $-0,0030$ & 0,001 & 10,5621 \\
\hline $\begin{array}{l}\text { 4. Microrregiões com } \\
\text { dinamismo cultural e } \\
\text { tecnológico }\end{array}$ & 0,2785 & $-0,0018$ & 0,0282 & $-0,0033$ & 0,001 & 9,9933 \\
\hline
\end{tabular}

Fonte: elaboração própria com base no software GeoDa. 
A existência dessa autocorrelação espacial é calculada por meio do $I$ de Moran. A seguir serão explorados os resultados obtidos, em que foram consideradas as matrizes de pesos espaciais que apresentaram o $I$ de Moran mais significativo para cada um dos 4 componentes principais. Para o componente 1 e do componente 3, foi usada a matriz de peso espacial do tipo Queen, para o componente 2 foi utilizada a matriz de peso espacial do tipo 2 vizinhos e para o componente 4 foi utilizada a matriz de peso espacial do tipo Rook.

A seguir, serão analisados na Figura 1 os mapas de clusters para todos os componentes, pois permitem uma melhor visualização dos resultados encontrados por meio dos diagramas de dispersão de Moran (Figura 1). Os mapas de clusters na Figura 2 mostram os padrões de associação espacial capturados pelo $I$ de Moran local e decompostos em quatro quadrantes. Nos mapas estão apenas as microrregiões que apresentaram significância estatística para o $I$ de Moran ao nível de significância de 5\% (ALMEIDA, 2004). O mapa de clusters tem por objetivo observar espacialmente o comportamento das microrregiões criativas, fornecendo um suporte visual para a observação das concentrações espaciais dos quatro componentes identificados.

Figura 1 - Mapas de clusters para os 4 componentes identificados na ACP
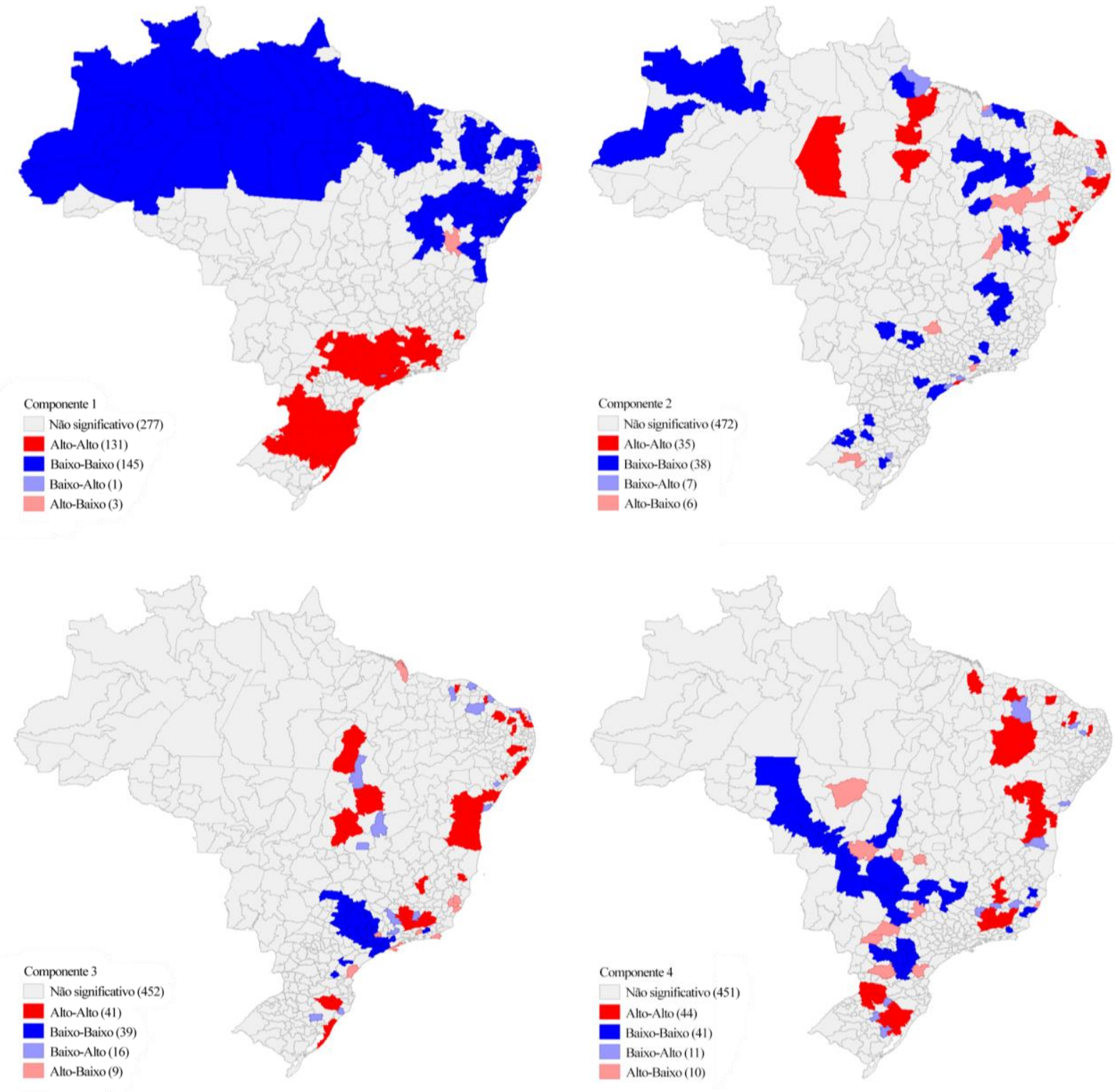

Fonte: Elaboração própria com base no software GeoDa

Como apresentado na metodologia, o diagrama de dispersão apresenta 4 tipos de associações espaciais, sendo elas: Alto-Alto, Baixo-Baixo, Alto-Baixo e Baixo-Alto. O agrupamento Alto-Alto indica altos valores para o componente em questão e microrregiões ao redor também com altos valores, ou seja, são microrregiões com alta capacidade criativa e desenvolvimento (no caso das microrregiões criativas e 
desenvolvidas) cercada de outras microrregiões com características similares. O agrupamento Baixo-Baixo indica que a microrregião tem baixa presença de determinado componente e seus vizinhos também. A relação Alto-Baixo mostra microrregiões com alto valor para o componente, mas seus vizinhos possuem baixo valor para o mesmo componente, a associação Baixo-Alto indica que a microrregião possui baixo valor para determinado componente e seus vizinhos possuem alto valor.

De acordo com a Figura 2, observa-se uma concentração de microrregiões criativas e desenvolvidas nas regiões Sul e Sudeste do Brasil e uma carência delas nas regiões Norte e Nordeste. Historicamente existe uma concentração de renda e de desenvolvimento nas regiões Sul e Sudeste e, isso se reflete ainda hoje nas regiões criativas caracterizadas no primeiro componente. Destaca-se que microrregiões com maior presença da classe criativa atrai indústrias criativas, bem como a presença de indústrias criativas também atrai a classe criativa de forma que a criatividade da região é fomentada (REIS, URANI, 2011). É oportuno destacar as associações do tipo Alto-Baixo que se encontram em: Recife (PE), João Pessoa (PB) e Seabra (BA) que se destacam como microrregiões com altos valores para o primeiro componente apesar de inseridas entre regiões com baixo valor para tal componente.

O segundo componente é caracterizado como microrregiões com alta densidade populacional e características socioeconômicas heterogêneas. Conforme já destacado, as microrregiões do segundo componente apresentam altos níveis de criminalidade apesar de também apresentarem empresas criativas, bem como trabalhadores criativos. Destaca-se também a presença da classe criativa em paralelo à presença da indústria criativa, fomentando a capacidade cultural e econômica das regiões (REIS, URANI, 2011). Logo, pode-se destacar capitais como: Fortaleza (CE), Natal (RN), Salvador (BA) e São Luís (MA), cidades com alta população e com destaque em empregabilidade no setor criativo, mas ainda deficitário quanto às questões de segurança.

As associações Alta-Alta para o terceiro componente (microrregiões com potencial turístico) estão presentes em áreas litorâneas do nordeste, com destaque para a Bahia, e regiões do centro-oeste e norte associadas a tradições, festividades e ecoturismo como: Dianópolis, Araguaína, Miracema do Tocantins. Vale também o destaque para a associação Baixo-Alto em Barbacena pois esta microrregião possui baixos valores para o componente 3 mas é cercada por microrregiões com altos valores para o terceiro componente como a microrregião de Oliveira, São João Del Rei, Juiz de Fora e Ubá, todas com associação Alto-Alto. O mesmo ocorre com Salvador e Natal. A importância do turismo, destacada anteriormente, é novamente destacada para enfatizar a relevância do setor para diversas microrregiões brasileiras que podem buscar, através do turismo, aumentar seu desempenho econômico. Logo, o turismo também é capaz de auxiliar as regiões a superar os déficits encontrados em suas economias (KAGEYAMA, 2011). A receita proveniente do turismo pode ser fundamental para microrregiões que são, em maioria, compostas por cidades pequenas e com baixa presença de grandes empresas criativas.

O quarto componente que caracteriza microrregiões com potencial cultural, ou seja, são lugares com forte presença de atividades artesanais e ligadas à tradição e o folclore, expresso em eventos culturais ou pontos históricos como ocorre com as cidades históricas na microrregião de São João Del Rei e Canindé. A região de Goiânia, por exemplo, pode ser destacada com uma associação Alta-Baixa, ou seja, a microrregião de Goiânia concentra altos valores para o quarto componente, possuindo potencial tecnológico e cultural, porém, as microrregiões ao redor não apresentam valores significativos. O mesmo tipo de associação acontece com Curitiba e Vitória. Dessa forma, há um equilíbrio entre o dinamismo cultural e seu potencial para o desenvolvimento de outras microrregiões (KAGEYAMA, 2011; MELGUZIO, 2011). Sobre a importância da tecnologia, ela é reforçada por diversos autores principalmente levando em conta os meios de produção das indústrias criativas, muito focados em capital intelectual e visando suprir necessidades de ordem intelectual, voltadas à estética e à experiência (BENDASOLLI et al, 2009; LIN, 2011; REIS e URANI, 2011).

Os resultados obtidos mostram que as microrregiões de perfil criativo e desenvolvido agregam forte presença de trabalhadores da classe criativa e baixa criminalidade, estão concentradas nas regiões sul e sudeste do Brasil, com padrão de associação Alta-Alta muito presente. Ressalta-se que as microrregiões desse componente possuem microrregiões vizinhas com características semelhantes, ou seja, regiões criativas e desenvolvidas estão cercadas de regiões também criativas e desenvolvidas. O mesmo ocorre com regiões de associação Baixa-Baixa, muito presentes nas regiões Norte e Nordeste, ou seja, a carência de desenvolvimento criativo observada nas regiões historicamente mais pobres do Brasil, se refletem nas microrregiões vizinhas (FLORIDA, 2004; REIS, 2011; REIS e URANI, 2011). Os resultados do segundo componente evidenciam as dificuldades que certas microrregiões têm em superar problemas ligados a segurança. Apesar da presença de empresas e trabalhadores criativos, essas microrregiões ainda sofrem com a criminalidade elevada, o que leva a uma menor atratividade da região (KAGEYAMA, 2011). No caso do terceiro componente, a associação Baixa-Baixa é concentrada na região do estado de São Paulo, tal resultado 
demonstra que as microrregiões possuem baixa relevância associada ao setor de turismo e as microrregiões vizinhas também possuem baixos valores para tal componente. A concentração Alta-Alta acontece na região sudeste de Minas Gerais, bem como no litoral nordestino e no centro-norte do Brasil, reforçando o turismo e a capacidade cultural que as regiões possuem e seus efeitos de transbordamentos para as regiões vizinhas (KAGEYAMA, 2011).

A associação Alta-Alta para o quarto componente é presente no sudeste de Minas Gerais bem como no interior do Nordeste e no centro da região Sul do Brasil. Essas regiões, além do forte contato cultural, possuem centros de desenvolvimento técnico e aparentam exibir os transbordamentos de conhecimento (spillovers) para as microrregiões vizinhas. A associação Baixa-Baixa concentra-se na região centro-oeste do Brasil, ou seja, as microrregiões do centro-oeste destacadas possuem baixo potencial tecnológico e cultural e as regiões ao redor seguem tal padrão.

\section{5- Considerações Finais}

O presente trabalho teve por objetivo identificar as microrregiões criativas brasileiras buscando caracterizar seu perfil e associação espacial. Os resultados apresentaram quatro perfis para as microrregiões brasileiras sendo estes definidos na análise de componentes principais (ACP) como microrregiões criativas e desenvolvidas, microrregiões densas e violentas, microrregiões com potencial turístico e microrregiões com dinamismo cultural e tecnológico. Ademais, por intermédio da análise exploratória de dados espaciais (AEDE), foi possível visualizar o comportamento espacial das microrregiões brasileiras de acordo com seus perfis.

De acordo com os resultados observou-se uma forte concentração nas regiões Sul e Sudeste de microrregiões com o perfil criativo e desenvolvido, enquanto no Norte e no Nordeste não foi possível caracterizar microrregiões com essas características. Os resultados também exibiram maior presença de microrregiões de perfil denso com características socioeconômicas heterogêneas na região Norte e Nordeste. Identificou-se que esse componente teve forte impacto da criminalidade, indicando que são microrregiões com deficiências em políticas regionais e no combate de desigualdades sociais.

Em relação as microrregiões com potencial turístico, também aparecem com concentração no litoral do Nordeste e locais de Minas Gerais e do Centro-Norte do Brasil, retratando as praias, o ecoturismo e pontos históricos. Por fim, o quarto componente é responsável por representar microrregiões com potencial cultural e tecnológico, em que se concentram polos educacionais, com forte presença de tradições e festividades culturais, concentradas em regiões do interior do Sul de Minas Gerais e da região Nordeste.

No entanto, o trabalho encontra limitação quanto às atividades informais, isto é, não foi possível captar e quantificar as atividades informais relacionadas ao setor criativo. Desta forma, a pesquisa se restringiu ao recorte microrregional com dados limitados temporalmente entre os anos de 2015 e 2020.

Por fim, os resultados apresentados contribuem para a literatura empírica da área em relação ao Brasil. No intuito de futuras contribuições à literatura na área de economia/cidades criativas, poder-se-ia examinar os efeitos de outras localidades com potencialidade criativa, no âmbito internacional. Além disso, um estudo mais aprofundado utilizando técnicas econométricas para mais períodos, permitiriam uma investigação mais detalhada sobre o tema, apontando suas potencialidades e fragilidades. 
Spatial profile of creative microregions in Brazil

Abstract : Creative cities can affect their economies, unite economic agents and benefit neighboring regions, ensuring demographic interaction and stimulating local actors concerned with cultural values and innovation. The general objective of the work was to identify, characterize and analyze the spatial profile and the creative capacity of Brazilian micro-regions. Through the analysis of principal components (ACP) and the exploratory analysis of spatial data (AEDE), Brazilian microregions were identified in four categories, based on the indicators covered in the literature. The results showed that the categories of creative and developed micro-regions, dense and violent micro-regions, micro-regions with tourist potential, and micro-regions with cultural and technological dynamism exhibit great differences in their creative profile, deepened by the country's economic and social inequalities.

Keywords: Creative microregions; Innovation; Regional Economy; Multivariate analysis.

\section{Referências bibliográficas}

ALMEIDA, E. S. DE. Curso de Econometria Espacial Aplicada. Piracicaba: [s.n.].

BARRETTO, L. Economia Criativa: potencial a explorar. In: REIS, Ana Carla Fonseca; KAGEYAMA, Peter (Org.). Cidades Criativas - perspectivas. 1 ed. São Paulo: Garimpo de Soluções \& Creative Cities Productions, 2011. p. 16.

BENDASSOLLI, P. F. et al. Indústrias Criativas: Definição, Limites E Possibilidades. Revista de Administração de Empresas, v. 49, n. 1, p. 10-18, 2009.

BILLE, Trine; SCHULZE, Günther G. Culture in Urban and Regional Development. In: GINSBURGH, Victor A.; THROSBY, David (ed). Handbook of the Economics of Art and Cuture. 1 ed.

Elsevier B.V., 2006. p. 1051 - 1099.

CAVES, R. Creative industries: contracts between art and commerce. Cambridge, Mass.: Harvard University Press, 2000.

CORAZZA, R. I. Criatividade, inovação e economia da cultura: abordagens multidisciplinares e ferramentas analíticas. Revista Brasileira de Inovação, Campinas (SP), v. 12, n. 1, p. 207231, 2013.

COSTA, A. D.; SOUZA-SANTOS, E. R. DE. Economia criativa: novas oportunidades baseadas no capital intelectual. Revista Economia \& Tecnologia, v. 7, n. 2, 2011.

FIRJAN. Mapeamento da Indústria Criativa no Brasil. p. 44, 2019.

FLORIDA, R. Cities and the creative class. American Sociological Association, p. 3-19, 2004. HONGYU et al. Análise de componentes principais: resumo teórico, aplicação e interpretação.

E\&S - Engeneering and Science. v.1 ed. 5. 2015. p. $83-90$.

KAGEYAMA, Peter. Cidade Criativa. In: REIS, Ana Carla Fonseca; KAGEYAMA, Peter (Org.).

Cidades Criativas - perspectivas. 1 ed. São Paulo: Garimpo de Soluções \& Creative Cities Productions, 2011. p. $54-59$.

LANDRY, C. The creative city: a toolkit for urban regeneration. 2. ed. Londres: Comedia earthscan, 2008. v. 36.

LIN, C. C. R. In: REIS, Ana Carla Fonseca; KAGEYAMA, Peter (Org.). Cidades Criativas perspectivas. 1 ed. São Paulo: Garimpo de Soluções \& Creative Cities Productions, 2011. p. 150 161.

MACHADO et al. Desenvolvimento urbano, Economia Criativa e produção solidária em uma metrópole brasileira. In: LEITÃO, C.; MACHADO, A. F. (Org.). Por uma Brasil Criativo: significados, desafios e perspectivas da economia criativa brasileira. 1. ed. Belo Horizonte: Código, 2016. cap.10, p. 239 - 267.

MARTINS, R. B. Lisboa, criativa?. In: REIS, Ana Carla Fonseca; KAGEYAMA, Peter (Org.). Cidades Criativas - perspectivas. 1 ed. São Paulo: Garimpo de Soluções \& Creative Cities Productions, 2011. p. $78-83$. 
MARTINS, Rolando Borges. Lisboa, criativa?. In: REIS, Ana Carla Fonseca; KAGEYAMA, Peter (Org.). Cidades Criativas - perspectivas. 1 ed. São Paulo: Garimpo de Soluções \& Creative Cities Productions, 2011. p. $78-83$.

MELGUIZO J. Medellin, uma cidade criativa. In: REIS, Ana Carla Fonseca; KAGEYAMA, Peter (Org.). Cidades Criativas - perspectivas. 1 ed. São Paulo: Garimpo de Soluções \& Creative Cities Productions, 2011. p. $44-49$.

NYKO, Diego; Zendron, Patricia. Economia Criativa. In: PUGA, Fernando Pimentel; CASTRO, Lavínia Barros de (Org.). Visão 2035 : Brasil, país desenvolvido : agendas setoriais para alcance da meta. 1. ed. Rio de Janeiro: Banco Nacional de Desenvolvimento Econômico e Social, 2018. 437 p. 259 - 288. ISBN 9788587545640.

OLIVEIRA et al. Economia criativa e cidades criativas: delimitação de conceitos e um breve estudo sobre o Polo Cinematográfico de Paulínia (SP). Temática, v. 11, n. 8, p. 109-121, 2015. OLIVEIRA, Luiz Antônio Gouveia. Cultura, criatividade e desenvolvimento territorial: reflexões sobre Redes e Sistemas Produtivos de Economia Criativa. In: LEITÃO, C.; MACHADO, A. F. (Org.). Por uma Brasil Criativo: significados, desafios e perspectivas da economia criativa brasileira. 1. ed. Belo Horizonte: Código, 2016. cap.6, p. 109 - 125.

PWC. Perspectives from the Global Entertainment and Media Outlook 2017-2021. p. 44, 2017. REIS, A. C. F. Cidades criativas - burilando um conceito em formação. IARA Revista de Moda, Cultura e Arte, v. 4, n. 1, p. 127-139, 2011.

REIS, A. C. F. Micro e pequenas empresas no cenário brasileiro - desafios e oportunidades. In: REIS, Ana Carla Fonseca; KAGEYAMA, Peter (Org.). Cidades Criativas - perspectivas. 1 ed. São Paulo: Garimpo de Soluções \& Creative Cities Productions, 2011. p. 162 - 169.

REIS, A. C. F.; URANI, A. Cidades criativas - perspectivas brasileiras. In: REIS, Ana Carla Fonseca; KAGEYAMA, Peter (Org.). Cidades Criativas - perspectivas. 1 ed. São Paulo: Garimpo de Soluções \& Creative Cities Productions, 2011. p. 30 - 37.

STRICKLAND, Bill. Cidade Criativa. In: REIS, Ana Carla Fonseca; KAGEYAMA, Peter (Org.). Cidades Criativas - perspectivas. 1 ed. São Paulo: Garimpo de Soluções \& Creative Cities Productions, 2011. p. $50-53$.

UNCTAD/DITC/TED. Trends in International Trade in Creative Industries. [s.l: s.n.]. UNCTAD/DITC, U. N. Creative Eonmoy Report 2008. [s.I: s.n.].

VIEIRA, E. T.; SANTOS, F. R.; CARNIELLO, M. F. Economia Criativa E O Desenvolvimento No Município De Taubaté-Sp. Revista Brasileria de Gestão e Desenvolvimetno Regional, v. 12, n. 2, p. 161-184, 2012. 
ANEXO I - ANÁLISE DESCRITIVA DOS DADOS

\begin{tabular}{|l|c|c|c|c|c|}
\hline \multicolumn{1}{|c|}{ Variáveis } & Observações & Média & $\begin{array}{c}\text { Desvio } \\
\text { Padrão }\end{array}$ & Mínimo & Máximo \\
\hline Educação & 558 & 3,513862 & 0,5661404 & 0 & 4,9 \\
Tecnologia & 558 & 0,0002254 & 0,0004488 & 0 & 0,0035285 \\
Pontos de Cultura & 558 & 0,001924 & 0,0002903 & 0 & 0,0033315 \\
Intensidade Criativa & 558 & 0,0830161 & 0,0601932 & 0,0004482 & 0,6345679 \\
Unidades Locais Criativas & 558 & 0,0272741 & 0,232062 & 0 & 5,083887 \\
Estabelecimentos Criativos & 558 & 0,0020376 & 0,0023357 & 0,0000455 & 0,0457367 \\
Turismo & 558 & 0,0016128 & 0,003104 & 0 & 0,0405096 \\
Cultura & 558 & 0,0005746 & 0,0006945 & 0 & 0,0064405 \\
Instituições Financeiras & 558 & 0,0008923 & 0,0010551 & 0 & 0,010953 \\
Produto Interno Bruto & 558 & 15323,75 & 9237,905 & 3850,958 & 62948,5 \\
Densidade Populacional & 558 & 68,85766 & 239,225 & 0,115532 & 2906,491 \\
Homicídios de 15 a 29 anos & 558 & 0,0001265 & 0,0001027 & 0 & 0,0006146 \\
Homicídios & 558 & 0,0002774 & 0,0001892 & 0 & 0,0013831 \\
\hline
\end{tabular}

Fonte: elaboração própria com base no STATA

ANEXO II - Matriz de correlação entre as variáveis

\begin{tabular}{|c|c|c|c|c|c|c|c|c|c|c|c|c|c|}
\hline & Educação & Tecnologia & $\begin{array}{c}\text { Pontos de } \\
\text { Cultura }\end{array}$ & $\begin{array}{l}\text { Intensidade } \\
\text { Criativa }\end{array}$ & $\begin{array}{c}\text { Unidades } \\
\text { Locais } \\
\text { Criativas }\end{array}$ & $\begin{array}{c}\text { Estabelecimentos } \\
\text { Criativos }\end{array}$ & Turismo & Cultura & $\begin{array}{l}\text { Instituições } \\
\text { Financeiras }\end{array}$ & $\begin{array}{c}\text { Produto } \\
\text { Interno } \\
\text { Bruto }\end{array}$ & \begin{tabular}{|c|} 
Densidade \\
Populacional
\end{tabular} & $\begin{array}{c}\text { Homicídios } \\
\text { de } 15 \text { a } 29 \\
\text { anos }\end{array}$ & Homicídios \\
\hline Educação & 1 & & & & & & & & & & & & \\
\hline Tecnologia & 0,2505 & 1 & & & & & & & & & & & \\
\hline Pontos de Cultura & 0,0526 & 0,1757 & 1 & & & & & & & & & & \\
\hline $\begin{array}{l}\text { Intensidade } \\
\text { Criativa }\end{array}$ & 0,2826 & 0,2912 & $-0,0174$ & 1 & & & & & & & & & \\
\hline $\begin{array}{l}\text { Unidades Locais } \\
\text { Criativas }\end{array}$ & 0,2489 & 0,4986 & 0,0283 & 0,4274 & 1 & & & & & & & & \\
\hline $\begin{array}{l}\text { Estabelecimentos } \\
\text { Criativos }\end{array}$ & 0,3022 & 0,3072 & $-0,0216$ & 0,6924 & 0,376 & 1 & & & & & & & \\
\hline Turismo & 0,1264 & 0,1432 & 0,0822 & 0,3952 & 0,1084 & 0,5919 & 1 & & & & & & \\
\hline Cultura & 0,2117 & 0,3872 & 0,2239 & 0,1653 & 0,1386 & 0,2283 & 0,3058 & 1 & & & & & \\
\hline $\begin{array}{l}\text { Instituições } \\
\text { Financeiras }\end{array}$ & 0,3108 & 0,2947 & $-0,0476$ & 0,3509 & 0,1599 & 0,6407 & 0,2832 & 0,2125 & 1 & & & & \\
\hline $\begin{array}{l}\text { Produto Interno } \\
\text { Bruto }\end{array}$ & 0,2321 & 0,3922 & $-0,0985$ & 0,3005 & 0,5185 & 0,4321 & 0,1358 & 0,1388 & 0,4458 & 1 & & & \\
\hline $\begin{array}{l}\text { Densidade } \\
\text { Populacional }\end{array}$ & 0,0369 & 0,1735 & $-0,04$ & 0,1274 & 0,3139 & 0,0622 & $-0,0036$ & $\mid-0,0791$ & 0,0237 & 0,1898 & 1 & & \\
\hline $\begin{array}{l}\text { Homicídios de } 15 \text { a } \\
29 \text { anos }\end{array}$ & $-0,2898$ & $-0,1336$ & $-0,0657$ & $-0,0165$ & $-0,0262$ & $-0,1897$ & $-0,0523$ & $-0,1509$ & $-0,2968$ & $-0,1442$ & 0,1184 & 1 & \\
\hline Homicídios & $-0,2951$ & $-0,1956$ & $-0,0873$ & $-0,0761$ & $-0,1335$ & $-0,2436$ & $-0,0887$ & $-0,1935$ & $-0,3008$ & $-0,1709$ & 0,0593 & 0,8413 & 1 \\
\hline
\end{tabular}

Fonte: elaboração própria com base no STATA 